\title{
SUBDIVISÃO CLINICA DO GRUPO DAS ESQUIZOFRENIAS
}

\author{
Neison Pires \\ Erico Novals Fir.ho \\ Alípio Castelo Branco
}

Rubim de Pinho

Manoel Gurrreiro

Gabriet Nery

Jacrues Coenho

Reconhecendo a atual imprestabilidade da subdivisão kraepeliniara, a dificuldade e a falacidade da de Carl Schneider, a inespecificidade de tôdas em geral e da de Kurt Schneider em particular (sintomas de primeira e segunda categoria, observados igualmente fora da esquizofrenia), abandonamos as doutrinas e estudamos cêrca de 80 casos, dos quais a metade curou. Tentamos a subdivisão considerando o prognóstico, quer dizer, a evolução em face dos tratamentos de choque. Procedemos à arálise estrutural de Birnbaum, recorrendo à fenomenologia de Jaspers, à escola alemã sobretudo (Carl e Kurt Schneider, Gruble, Mayer-Gross, Kretschmer, Bunke, Lange, Bleuler, Langfeldt, Mauz) e aos dados tirados do livro de Max Müller, sôbre o prognóstico. Não tínhamos idéia preconcebida quanto cos resultados. Trabalhamos em equipe de sete, porém isoladamente. Nossos casos curados permanecem em remissão de 3 a 6 anos.

0 estudo da sintomatologia nos permitiu concluir que as esquizofrenias que se caracterizam pelo esvaziamento afetivo com patoplastia pobre são quase sempre malignas; a dificuldade residiu em conseguir separar, psicopatològicamente, a pobreza de sintomas daquilo que se lhe assemelha a inibição depressiva; esta última tem prognóstico favorável, diametralmente oposto ao que sucede com os introvertidos pobres e inafetivos.

As formas típicas, quer dizer, aquelas que não dão margem a dúvida alguma nem apresentam qualquer dificuldade quanto ao diagnóstico diferencial, notadamente a sintomatologia da demência precoce (Morel-Kraepelin) - excluem-se naturalmente as formas paranóicas, parafrênicas e paranóides - às quais se ajuntam aquelas formas esquizof rênicas que são puras continuações ou acentuações que cresceram imperceptivelmente partindo da personalidade anterior, pré-psicótica, são claramente distintas de tôdas as demais. Não pensávamos nas reações gerais homônimas e heterônimas de Kleist. Mas, a viva reação da personalidade observada em um grupo se opõe claramente à invasão insidiosa, silenciosa, do outro grupo que jamais atingirá a cura. Assim, o grupo de sintomatologia rica, produtiva, estênica, hipertímica, mais ou menos matizada com traços expansivos ou depressivos, oníricos, paranóicos, histéricos e motores (agitação), foi curado ou muito melhorado, em sua grande maioria, pelos tratamentos do choque, no primeiro

Trabalho do Sanatório Bahia (Salvador - Bahia), apresentado ao $19^{\circ}$ Congresso Internacional de Psiquiatria (Paris, setembro de 1950). 
surto da esquizofrenia. No segundo surto, esta mesma tonalidadc. seja pura ou impurificada por misturas e inclusões várias, não é mais henigna (em nossa casuística os $100 \%$ de cura no primeiro surto, reduziram-se a $45 \%$ no segundo surto, que sobreveio num lapso de tempo de 6 a 24 meses depois). As esquizof renias com evolução em surtos, que, em nossa casuística, foram dadas como curadas, haviam suscitado dúvidas com as psicoses reativas, com estados de "defeito esquizofrênico" ativados por um conflito ou, ainda, com as "psicoses de motilidade" (Kleist). Finalmente, comparando o grupo que curou fàcilmente com o grupo que não curou nunca, não verificamos qualquer diferenciação sintomatológica, a não ser a seguinte: a introversão inafetiva era quase sempre catastrófica, ma esta jamais se apresentou no grupo de evolução em surtos, grupo curável. Tampouco se apresentou catástrofe quando a síndrome era de depressão ruidosa.

A idade, aferida nos nossos doentes, confirmou as afirmações de MorelKraepelin, que datam de era anterior à dos tratamentos de choque: as esquizofrenias que surgem ao redor dos 18 a 21 anos de idade sáo pouco acessiveis às terapêuticas de choque, contràriamente ao que acontece com as esquizofrenias que sobrevêm entre os 30 e os 45 anos.

A estrutura corporal não forneceu resultado algum. Nossos pícnicos eram muito raros, as formas corporais atléticas (puras ou impuras) foram desfavoráveis, mas não obtivemos indicação quanto aos leptossomáticos, fôssem êles de forma extrema ou não. Ao contrário, o temperamento alegre revelou-se claramente favorável, maximé nos extrovertidos francos.

Finalmente, a hereditariedade nos revelou um dado surpreendente: os esquizof rênicos que tinham, na parentela, casos de epilepsia, de oligofrenia ou de malformações corporais (quase sempre havia mais de um parente doente) se mostraram, no grupo não curado, em número duas vêzes maior que no grupo dos curados. Notamos haver, nestes dois grupos, uma freqüência igual de parentes portadores de psicoses curadas ou crônicas, isto é, que a esquizofrenia evoluía sem paralelismo prognóstico com a esquizofrenia do parente.

De tudo pensamos ser legítimo propor a subdivisão seguinte:

1. Grupo -- Esquizofrenias que sobrevêm antes dos 30 anos, com sintomatologia axial de introversão verdadeiramente inafetiva, patoplastia acentuadamente pobre, personalidade anterior sem sintonia, sem estenia, sem hi: pertimia. São em regra incuráveis.

2. Grupo - Esquizofrenias que sobrevêm em qualquer idade, com sintomatologia variável desde os quadros aparentemente psicógeno-reativos (no sentido de Jaspers), aos exógenos (Bonhoeffer), às psicoses da motilidade (Kleist), ricos de traços onírico-paranóides e de estados crepusculares obscuros Momentos exógenos como o puerpério, as intervenções cirúrgicas, etc., provocam tais psicoses. São em geral curáveis. Lembram as psicoses de reação e as exógenas. 
$3 .^{\circ}$ Grupo - Esquizofrenias em surtos. a) Formas nitidamente depressivas: a personalidade anterior ordinàriamente era afetuosa, capaz de amizade, de contacto afetivo e de atividade, apesar da timidez e da inibição aparentes, quando não era francamente alegre. A esquizofrenia nestes casos começou como estado reativo, psicógeno e, freqüentemente, teve início súbito ou mesmo explosivo (lembramo-nos das "Schizoidpsychosen" de Lange-Poppers). São em geral eminentemente curáveis. b) Formas com inclusões diversas: paranóides (do tipo delírio sensitivo agudo), introversivas progressivas (cada surto impele a sintomatologia para a introversão crescente), catatônicas hiper ou acinéticas. Lembramos as "psicoses degenerativas" de Kleist, mas há outras psicoses esquizofrênicas fora dêsse grupo assemelhado. Neste subgrupo a cura é cada vez mais difícil quando os surtos se sucedem, sobretudo se a sintomatologia ultrapassa a depressão pura. O prognóstico é geralmente mau, mas ainda há casos curáveis. Neste subgrupo o diagnóstico não oferece dúvidas desde o princípio. c) Esquizofrenias tardias.

Ùnicamente os grupos 2 e $3 a$ são benígnos. $O$ grupo $3 b$ tem ainda um número restrito de curas. Não temos grande experiência quanto às formas tardias.

A qualidade dos sintomas isolados ou de síndromes completas ("ação exterior" de Claude, "automatismo mental" de Clérambault), a utilização de dados como "primäre Symptome", "Wahnideen", "Wahnwahrnehmungen", "Ichsstörungen", síndromes de primeira e de segunda categoria (Kurt Schneider), etc., revelaram-se completamente inúteis para qualquer prognóstico em face dos tratamentos de choque. As esquizofrenias remitiam ou não, sem predomínio, indiferentes à presença ou ausência de tais sintomas ou síndromes.

Sanatório Bahia - Salvador, Brasil. 